deau (7) for the maintenance of cardiovascular tone in adult animals. Furthermore, the inter-relationship of adrenergic neuronal and humoral elements also occurs within the adrenal gland itself because sympathetic innervation of the adrenal medulla appears to be essential for the proper discharge of $E$ into the circulation during hypoxia. Before the development of the sympathetic nerve supply to the adrenal gland during the final quarter of gestation, the hypertensive response of the fetus to hypoxia appears to be regulated adequately by the interaction of the sympathetic nervous system and adrenal medullary NE release $(14,15)$.

\section{REFERENCES AND NOTES}

1. Barcroft, J.: Researches on prenatal life. (Blackwell, Oxford, 1946).

2. Born, G. V. R. Dawes, G. S., and Mott, J. C.: Oxygen lack and autonomic neurons control of the faetel circulation in the lamb. J. Physiol. (London), 134: 149 (1956).

3. Cohen, H. E., Sacks, E. J., Heymann, M. A., and Rudolph, A. M.: Cardiovascular responses to hypoxemia and acidemia in fetal lambs. Am. J. Obstet. Gynecol., 120: 817 (1974).

4. Comline, R. S. and Silver, M.: The release of adrenaline and noradrenaline from the adrenal glands in the fetal sheep. J. Physiol., 156: 424 (1961).

5. Comline, R. S., Silver, I. A., and Silver, M.: Factors responsible for the stimulation of the adrenal medulla during asphyxia in the faetal lamb. J. Physiol., 178: 211 (1965).

6. DeChamplain, J.: Degeneration and regrowth of adrenergic nerve fibers in the rat peripheral tissues after 6-hydroxydopamine. Can. J. Physiol. Pharmacol., 49: 345 (1971).

7. DeChamplain, J. and Nadeau, R. A.: 6-hydroxydopamine, 6-hydroxydopa and degeneration of adrenergic nerves. Fed. Proc., 30:877 (1971)

8. Eliot, R. J., Klein, A. H., Glatz, T. H., Lam, R. Palmer, S., Padgett, D., and Fisher, D. A.: Norepinephrine, epinephrine and dopamine levels in response to hypoxia in neonatal lambs. Clin Res., 27: 124A (1979).

9. Gauthier, P., Nadeau, R., and DeChamplain, J.: Acute and chronic cardiovascular effects of 6-hydroxydopamine in dogs. Circ. Res., 31: 207 (1972).

10. Gauthier, P., Nadeau, R., and DeChamplain, J.: Cardiovascular reactivity in the dog after chemical sympathectomy with 6-hydroxydopamine. Can. J. Physiol. Pharmacol., 52: 590 (1974).

11. Haeusler, G., Haefely, W., and Thoenen, H.: Chemical sympathectomy of the cat with 6-OH-DA. J. Pharmacol. Exp. Ther., 170: 50 (1969).

12. Heymann, M. A. and Rudolph, A. M.: Effect of exteriorization of the sheep fetus on its cardiovascular function. Circ. Res., 21: 741 (1967).

13. Jones, C. T. and Robinson, R. O.: Plasma catecholamines in faetal and adult sheep. J. Physiol., 248: 15 (1975).

14. Lewis, A. B., Donovan, M., and Platzker, A. C. G.: Cardiovascular responses to autonomic blockade in hypoxemic fetal lambs. Biol. Neonate, 37: 233 (1980).

15. Lewis, A. B., Evans, W. N., and Sischo, W.: Plasma catecholamine responses to hypoxemia in fetal lambs. Biol. Neonate, 41: 115 (1982)

16. Lewis, A. B., Nestor, L., Dahms, B., and Platzker, A. V. B.: Cardiovascular responses to autonomic blockade in brain-injured fetal lambs. Biol. Neonate, 34: 97 (1978).

17. Mueller, R. A.: Effect of 6-hydroxydopamine on the synthesis and turnover of catecholamines and protein in the adrenal. In: T. Malmfors and $H$. Thoenen, Eds.: 6-Hydroxydopamine and Catecholamine Neurons. pp, 291-300 (North Holland Publishing Company, 1971).

18. Passon, P. G. and Peuler, J. D.: A simplified radiometric assay for plasma norepinephrine and epinephrine. Anal. Biochem., 51: 618 (1973).

19. Peuler, J. D. and Johnson, G. A.: A sensitive radioenzymatic assay of plasma catecholamines: Initial studies in supine normotensive subjects. Clin. Res. 23: 474A (1975).

20. Porlier, G. A., Nadeau, R. A., De Champlain, J., and Bichet, D. G.: Increased circulating plasma catecholamines and plasma renin activity in dogs after chemical sympathectomy with 6-hydroxydopamine. Can. J. Physiol. Pharmacol., 55: 724 (1977).

21. Porter, C. C., Totaro, J. A. and Stone, C. A.: Effect of 6-hydroxydopamine and some other compounds on the concentration of norepinephrine in the hearts of mice. J. Pharmacol. Exp. Ther., 140: 308 (1963).

22. Tranzer, J. P. and Thoenen, H.: Electron microscopic study of selective acute degeneration of sympathetic nerve terminals after administration of 6hydroxydopamine. Experimentia, 24: 155 (1968).

23. Vapaavouri, E. K., Shinebourne, E. A., Williams, R. L., Heymann, M. A., and Rudolph, A. M.: Development of cardiovascular responses to autonomic blockade in intact fetal and neonatal lambs. Biol. Neonate, 22: 177 (1973).

24. Requests for reprints should be addressed to: Dr. Alan B. Lewis, Division of Cardiology, Children's Hospital of Los Angeles, 4650 Sunset Blvd., P.O. Box 54700, Los Angeles, CA 90054-0700.

25. Funded in part by grants from the Kenneth T. and Eileen L. Norris Foundation and the Childrens Heart Foundation of Southern California.

26. The authors gratefully acknowledge the secretarial assistance of Ms. T. Rickerson in the preparation of this manuscript.

27. Received for publication December 7, 1982.

28. Accepted for publication June 15, 1983 .

\title{
The Effects of Opiate Antagonism on Gonadotropin Secretion in Children and in Women with Hypothalamic Amenorrhea
}

\author{
S. E. SAUdER, ${ }^{(33)}$ G. D. CASE, N. J. HOPWOOD, R. P. KELCH, AND J. C. MARSHALL \\ Departments of Pediatrics and Communicable Diseases and Internal Medicine and the Reproductive \\ Endocrinology Program, University of Michigan, Ann Arbor, Michigan, USA
}

\section{Summary}

The effects of opiate antagonism [naloxone infusion, $1 \mathrm{mg} /\left(\mathrm{m}^{2}\right.$. h)] on gonadotropin secretion were examined in four children (one female and three males: two late prepubertal and two pubertal; chronologic age, range 11.8-15.9 yr; bone age, range 8.5-13.5 yr) and in four women with hypothalamic amenorrhea (two at normal body weight and two at low body weight). Naloxone had no effect on daytime gonadotropin secretion in three children who were biologically the youngest in the group, two late prepubertal and one early pubertal [plasma luteinizing hormone $(\mathrm{LH}) \overline{\boldsymbol{x}} \pm \mathrm{SE}$ : control day, $1.2 \pm 0.1$; control night, $4.5 \pm$ 0.4 ; and naloxone day, $1.3 \pm 0.1 \mathrm{mIU} / \mathrm{ml}$. In contrast, opiate blockade produced a slight but discernible increase in plasma LH in the child whose hypothalamic-pituitary-gonadal axis was the most mature, a boy at mid-puberty. Naloxone produced a striking increase in plasma $\mathrm{LH}$ in the amenorrheic women at normal body weight (LH, $\bar{x} \pm \mathrm{SE}$ : control day, $3.4 \pm 0.3$; control night, 7.0 \pm 1.0 ; and naloxone day, $7.4 \pm 0.7 \mathrm{mIU} / \mathrm{ml}$ ) as well as in those at low body weight (LH, $\bar{x} \pm \mathrm{SE}$ : control day, $3.5 \pm 0.3$; 
control night, $2.8 \pm 0.2$; naloxone day, $4.9 \pm 0.4$; and naloxone night, $6.7 \pm 0.5 \mathrm{mIU} / \mathrm{ml})$. Antagonism of endogenous opiate activity increased LH pulse frequency in all four women. These findings suggest the following conclusions: 1 ) the mechanisms responsible for the reduced $\mathrm{LH}$ secretion in some women with hypothalamic amenorrhea differ from those in late prepubertal and early pubertal children, and 2) endogenous opiates affect LH pulse frequency by acting at the hypothalamic level to change gonadotropin-releasing hormone pulse frequency.

\section{Abbreviations}

\section{BA, bone age \\ CA, chronologic age \\ CNS, central nervous system \\ DHEAS, dehydroepiandrosterone sulfate \\ $\mathbf{E}_{2}$, estradiol}

FSH, follicle-stimulating hormone

GnRH, gonadotropin-releasing hormone

IBW, ideal body weight

IRP, International Reference Preparation

LH, luteinizing hormone

PRL, prolactin

$T$, testosterone

Endogenous opioid peptides may be important modulators of gonadotropin secretion in humans. In normal men, administration of a long acting enkephalin analog decreases serum gonadotropin concentrations (27) whereas competitive antagonism of endogenous opiates by naloxone results in increased serum $\mathrm{LH}$ and FSH (20). Similarly, naloxone increases serum LH in normal women during the late follicular and midluteal phases of the menstrual cycle (22). Although the exact mechanisms by which endogenous opiates influence gonadotropin secretion have not been determined conclusively, the site of action appears to be at the hypothalamic level. Opioid peptides have been shown to affect release of $\mathrm{GnRH}$ : met-enkephalin decreases $\mathrm{K}^{+}$-induced $\mathrm{GnRH}$ release (8) and naloxone increases GnRH release (29) from medial basal hypothalamic nerve terminals in rats.

Maturation of the hypothalamic-pituitary-gonadal system in humans is characterized by several phases. After a period of increased activity during fetal life and early infancy, this system is suppressed during mid-childhood, and then is reactivated at the time of puberty. The low gonadotropin secretion found during mid-childhood is postulated to be due to suppression of GnRH secretion by two mechanisms: 1 ) increased sensitivity of the hypothalamus, and possibly the pituitary gland, to the negative feedback effects of gonadal steroids, and 2) inhibition by a CNS regulatory mechanism that is independent of gonadal steroid feedback influences (23). This sex steroid-independent "intrinsic" CNS inhibitory mechanism is suggested by the striking fall in gonadotropin secretion in agonadal children 4-11 yr of age (7). Recently, we showed that, despite the suppressed hypothalamic-pituitary activity during mid-childhood, LH pulses are detectable during the day and night and that mean plasma $\mathrm{LH}$ concentrations are greater at night than during the day (15). The onset of puberty is accompanied by augmentation of the day/ night difference in gonadotropin secretion.

The purpose of this study was to investigate a possible role of endogenous opiates in suppression of gonadotropin secretion during childhood. In particular, we studied the importance of opioid peptides in determining the day/night difference in $\mathrm{LH}$ and FSH secretion. To answer this question, the effects of opiate antagonism by naloxone on daytime gonadotropin secretion were determined in two late prepubertal and two pubertal children who had plasma gonadotropin concentrations which were low during the day and increased at night during sleep.

For comparison, similar studies of the effects of naloxone on gonadotropin secretion were performed in four women with hypothalamic amenorrhea who had immature patterns of $\mathrm{LH}$ and FSH secretion. Two of the women had low LH secretion during the daytime only, resulting in a day/night difference in plasma LH similar to the children studied. In the other two women who were at low body weight, $\mathrm{LH}$ was suppressed during the night as well as during the day.

\section{MATERIALS AND METHODS}

Children. After evaluation for "short stature" and/or "delayed adolescence," all children in this group were found to be endocrinologically normal (Table 1). Based on clinical criteria (16), two children were prepubertal (subjects 1 and 2) and two had entered into puberty $\left(P_{2}\right.$ and $P_{3}$ in subjects 3 and 4 , respectively).

Women with hypothalamic amenorrhea. The four women in this group were divided into subgroups based on body weight (Table 1) and gonadotropin secretory patterns. Subjects 5 and 6 were at normal body weight. Subject 5 had experienced irregular menstrual periods for $8 \mathrm{yr}$ before beginning oral contraceptives at 23 years of age. Subject 6 had menstruated regularly for $5 \mathrm{yr}$ before beginning oral contraceptives at age $19 \mathrm{yr}$. After stopping the medication, spontaneous menses did not occur during the subsequent 18 and 9 mo in subjects 5 and 6 , respectively. Neither woman had evidence of galactorrhea or hirsutism. Serum thyroxine and PRL concentrations as well as radiologic studies of the sella turcica were normal.

Subjects 7 and 8 were at low body weight. Subject 7 had menarche at age $14 \mathrm{yr}$, but her menstrual periods were markedly irregular until age 18 at which time her weight fell from 100 to $85 \%$ of IBW. Afterwards, she had amenorrhea for $7 \mathrm{yr}$. After endocrinologic evaluation revealed no other abnormalities, selfinduced weight loss as well as ongoing psychologic stress were felt to be the cause of the secondary amenorrhea. Subject 8 had menarche at $13 \mathrm{yr}$ of age and had irregular, spontaneous menses until age 19 when she began oral contraceptives. At age $28 \mathrm{yr}$, she stopped the medication and began a weight reduction program which resulted in a decrease from 100 to $74 \%$ IBW. No spontaneous menses occurred over the subsequent 3 yr during which time her weight remained below $80 \%$ IBW. Endocrinologic evaluation led to the diagnosis of anorexia nervosa.

Study design. Before study, written informed consent was obtained from the parent and/or subject, as appropriate. The study protocol was approved by the Human Investigation Committee of the University of Michigan.

Study subjects were admitted to the Clinical Research Center on the day ( $\mathrm{d} 0$ ) before initiation of blood sampling to allow acclimatization to the unit. An intravenous cannula was placed in a forearm vein for administration of normal saline or naloxone by a Harvard continous infusion pump. Frequent blood samples were obtained via a 21 gauge scalp vein needle (Abbott Butterfly, Abbott Hospitals, Inc., N. Chicago, IL), which was placed in the opposite forearm. This cannula was irrigated intermittently with a dilute solution of heparinized saline.

On d 1, a control infusion of normal saline $(20 \mathrm{ml} / \mathrm{h} \mathrm{IV})$ was administered from $1000-1800 \mathrm{~h}$ in subjects 1 through 4 and from $1000-2000 \mathrm{~h}$ in subjects 5 and 6 . Subjects 7 and 8 received saline infusions over $24 \mathrm{~h}$ on $\mathrm{d} 1$ and 3 . On d 2, naloxone hydrochloride (Narcan, Endo Laboratories, Inc., Wilmington, DE) was infused at a rate of $1.0 \mathrm{mg} /\left(\mathrm{m}^{2} \cdot \mathrm{h}\right)$ per $20 \mathrm{ml}$ normal saline during the following time periods: $1200-1600 \mathrm{~h}$ in subjects $1-4,1200-1800 \mathrm{~h}$ in subjects 5 and 6 , and $1200-0900 \mathrm{~h}(\mathrm{~d} \mathrm{3})$ in subjects 7 and 8 . Subjects 1 through 6 received saline during the $2 \mathrm{~h}$ before and after naloxone. In subjects 7 and 8, 24-h control saline infusions were administered immediately before and after naloxone. Subjects were not permitted to drink caffeinated beverages and were not allowed to sleep during the day. At night, sleep patterns were monitored visually and recorded frequently by the nursing staff.

LH and FSH secretory patterns were determined from blood samples obtained every $20 \mathrm{~min}$. Lengths of blood sampling 
Table 1. Study subjects: clinical characteristics and hormone concentrations*

\begin{tabular}{|c|c|c|c|c|c|c|c|c|}
\hline & $\begin{array}{l}\text { Subject } \\
\text { No./sex } \\
\end{array}$ & $\begin{array}{c}\text { CA/BA } \\
(\mathrm{yr})\end{array}$ & $\begin{array}{c}\text { Height }(\mathrm{cm}) / \\
\text { weight }(\mathrm{kg})\end{array}$ & & $\begin{array}{c}\Delta \max \mathrm{LH} / \Delta \max \\
\mathrm{FSH} \dagger \\
(\mathrm{mIU} / \mathrm{ml})\end{array}$ & $\begin{array}{c}\text { Testosterone } \neq \\
(\mathrm{ng} / \mathrm{ml})\end{array}$ & $\begin{array}{c}\text { Estradiol } \ddagger \\
(\mathrm{pg} / \mathrm{ml})\end{array}$ & $\begin{array}{c}\text { DHEAS } \\
(\mu / \mathrm{dl})\end{array}$ \\
\hline \multirow[t]{3}{*}{$\begin{array}{l}\text { Late Prepubertal and } \\
\text { pubertal children }\end{array}$} & $1 / F$ & $11.8 / 8.5$ & $132 / 23$ & & $16.4 / 12.4$ & $\ldots$ & $\begin{array}{l}22 \pm 5 \\
(11-34)\end{array}$ & 19 \\
\hline & $2 / \mathrm{M}$ & $14.9 / 11.0$ & $138 / 30$ & & $18.2 / 1.3$ & $\begin{array}{c}0.5 \pm 0.1 \\
(0.3-0.6)\end{array}$ & $\cdots$ & 8 \\
\hline & $3 / \mathrm{M}$ & $15.9 / 13.0$ & $151 / 39$ & & $12.7 / 2.1$ & $\begin{array}{l}0.6 \pm 0.1 \\
(0.4-0.7)\end{array}$ & $\ldots$ & 166 \\
\hline \multirow[t]{2}{*}{$\begin{array}{l}\text { Women with hypo- } \\
\text { thalamic amenorrhea }\end{array}$} & $5 / \mathrm{F}$ & 31/adult & $158 / 48$ & & $125.8 / 15.9$ & $\ldots$ & $\begin{array}{c}50 \pm 8 \\
(34-79)\end{array}$ & 50 \\
\hline & $6 / F$ & 21/adult & $165 / 56$ & & $64.0 / 21.2$ & $\ldots$ & $\begin{array}{c}26 \pm 3 \\
(16-31)\end{array}$ & 126 \\
\hline \multirow{3}{*}{\multicolumn{2}{|c|}{$\begin{array}{l}\text { Range of normal val- } \\
\text { ues§ }\end{array}$}} & & $\begin{array}{l}\text { Prepubertal } \\
\text { children } \\
(\mathrm{BA}, 2-10 \mathrm{yr})\end{array}$ & $\frac{1}{q}$ & $\begin{array}{r}6-139 / 6-44 \\
3-20 / 2-25\end{array}$ & $0 . \ddot{1-0.5}$ & $\begin{array}{c}10-30 \\
\ldots\end{array}$ & $\begin{array}{l}5-30 \\
5-30\end{array}$ \\
\hline & & & $\begin{array}{l}\text { Early pubertal } \delta \\
\text { (BA, 10-13 } \\
\text { yr) }\end{array}$ & & $4-84 / 1-30$ & $0.2-6.0$ & $\ldots$ & $30-200$ \\
\hline & & & $\begin{array}{l}\text { Adult } \$ \text {, early- } \\
\text { follicular } \\
\text { phase }\end{array}$ & & $33-160 / 2-17$ & $\ldots$ & $22-66$ & $50-300$ \\
\hline
\end{tabular}

*Abbreviations: CA, chronologic age; BA, bone age; LH, luteinizing hormone; FSH, follicle stimulating hormone; and DHEAS, dehydroepiandrosterone sulfate.

$\dagger$ Maximum incremental responses to synthetic GnRH $(2.5 \mu \mathrm{g} / \mathrm{kg})$.

$\ddagger \bar{x} \pm$ SE for values obtained on study $\mathrm{d} 1$ and 2 before naloxone infusion, ( ) = range.

$\S$ References 17 and 25.

periods were determined by body weight and total blood withdrawal did not exceed $10 \%$ of estimated blood volume. In subjects 1 through 6 , plasma $\mathrm{T}$ or $\mathrm{E}_{2}$ was measured at $0800 \mathrm{~h}$, $1600 \mathrm{~h}$, and $2400 \mathrm{~h}$ on $\mathrm{d} 1$ and at $0800 \mathrm{~h}, 1200 \mathrm{~h}, 1600 \mathrm{~h}$, and $2000 \mathrm{~h}$ on $\mathrm{d} 2$. Plasma $\mathrm{E}_{2}$ was measured every $12 \mathrm{~h}$ on $\mathrm{d} 1$ through 3 in subjects 7 and 8 . Cortisol and PRL were determined in hourly blood samples drawn during saline and naloxone infusions; in addition, PRL was measured hourly during sleep. Due to blood volume considerations, PRL was not measured in Subject 1. Plasma DHEAS was measured at $0800 \mathrm{~h}$. Gonadotropin responses to a standardized dose of synthetic GnRH $(2.5 \mu \mathrm{g} /$ $\mathrm{kg}$ IV bolus) were determined on $\mathrm{d} 3$ in subjects 1 through 4 and within the 5 mo preceding this study in subjects 5 and $6(25)$.

Assays and analyses. Plasma LH and FSH concentrations were determined by radioimmunoassay $(18,19)$. The first IRP pituitary FSH/LH (Medical Research Council 69/104) was used as the assay standard; gonadotropin values were converted to mIU of 2nd IRP of human menopausal gonadotropin and are expressed in terms of this urinary standard. Plasma $T, E_{2}$, cortisol, PRL, and DHEAS were measured by radioimmunoassay (1, $5,9,14,26)$.

Mean gonadotropin concentrations were determined by calculating the arithmetic means of $\mathrm{LH}$ and FSH values obtained at 20-min intervals. A significant $\mathrm{LH}$ pulse was defined as an increment from nadir to peak occurring within $40 \mathrm{~min}$, which was at least twice the corresponding intra-assay coefficient of variation. For plasma $\mathrm{LH}$ concentrations of $2.5,7.5$, and 15 $\mathrm{mIU} / \mathrm{ml}$, the intra-assay coefficients of variation averaged 20 , 9.5 , and $6.6 \%$, respectively.

Student's paired $t$ test was performed to determine significance of differences in mean gonadotropin concentrations between the control and naloxone studies in the children. Skeletal age was assessed according to the standards of Gruelich and Pyle (11).

\section{RESULTS}

In the children (subjects 1-4), LH and FSH responses to GnRH and plasma concentrations of $\mathrm{T}, \mathrm{E}_{2}$, and DHEAS were appropriate for their corresponding degrees of skeletal maturity (Table 1) (25). In response to the preceding nocturnal increase in LH secretion, $T$ values in the three boys were highest at $0800 \mathrm{~h}[\mathrm{~T}$, $\bar{x}$ (range): $0800 \mathrm{~h}, 2.1(0.6-6.1)$ and $2000-2400 \mathrm{~h}, 1.6(0.1-3.9)$ $\mathrm{ng} / \mathrm{ml}$ ]. Similarly, $\mathrm{E}_{2}$ in subject 1 , a late prepubertal girl, was greatest during the day $\left[E_{2}, \bar{x}\right.$ (range): $0800-1600 \mathrm{~h}, 22(15-34)$ and $2000-2400 \mathrm{~h}, 10.5(10-11) \mathrm{pg} / \mathrm{ml})$.

Gonadotropin responses to a standard dose of synthetic $\mathrm{GnRH}$ in subjects 5 and 6 were comparable to those found in normal adult females during the follicular phase of the menstrual cycle (Table 1) (17). In all women, basal $E_{2}$ concentrations were compatible with early follicular range values and did not show diurnal variation.

Mean plasma LH increased significantly $(P<0.05)$ during sleep in the children (Table 2). Patterns of augmented nocturnal LH pulses in individual subjects are shown in Figure 1. Plasma FSH was also increased during sleep in the late prepubertal girl (subject 1). When the studies were analyzed together, naloxone had no effect on mean gonadotropin concentrations or on LH pulse frequency and amplitude in the three children who were biologically the youngest in the group, subjects 1-3 (Table 2). In contrast, opiate blockade produced a slight but discernible increase in plasma LH in subject 4 (Table 2), a boy whose hypothalamic-pituitary-gonadal axis was more mature as indicated 
Table 2. Effects of naloxone on luteinizing hormone ( $\mathrm{LH}$ ) secretion in children and in women with hypothalamic amenorrhea

\begin{tabular}{|c|c|c|c|c|c|c|}
\hline \multirow{2}{*}{$\begin{array}{l}\text { Subject } \\
\text { No. }\end{array}$} & \multicolumn{2}{|c|}{ Day 1 (control) } & \multicolumn{2}{|c|}{ Day 2 (naloxone) } & \multicolumn{2}{|c|}{ Day 3 (control) } \\
\hline & Day & Night & Day & Night & Day & Night \\
\hline \multicolumn{7}{|l|}{$1-3^{*}$} \\
\hline Mean plasma LH§ & $1.2 \pm 0.1$ & $4.5 \pm 0.4$ & $1.3 \pm 0.1$ & $\ldots$ & $\ldots$ & $\ldots$ \\
\hline No. LH pulses\| & 1 & 8 & 2 & $\ldots$ & $\ldots$ & $\ldots$ \\
\hline LH pulse amplitude§ & 1.3 & $2.2 \pm 0.4$ & $1.5 \pm 0.2$ & $\ldots$ & $\ldots$ & $\ldots$ \\
\hline \multicolumn{7}{|l|}{$4^{*}$} \\
\hline Mean plasma LH§ & $5.0 \pm 0.2$ & $10.8 \pm 0.8$ & $6.3 \pm 0.4$ & .. & $\ldots$ & $\cdots$ \\
\hline No. LH pulses\| & 3 & 2 & 3 & $\ldots$ & $\ldots$ & $\ldots$ \\
\hline LH pulse amplitude§ & $1.8 \pm 0.5$ & $7.4 \pm 1.3$ & $2.7 \pm 0.6$ & $\ldots$ & .. & $\ldots$ \\
\hline \multicolumn{7}{|l|}{$5-6 \dagger$} \\
\hline Mean plasma LH§ & $3.4 \pm 0.3$ & $7.0 \pm 1.0$ & $7.4 \pm 0.7$ & $\cdots$ & $\ldots$ & $\ldots$ \\
\hline No. LH pulses\| & 1 & 3 & 5 & $\ldots$ & $\cdots$ & $\cdots$ \\
\hline $\begin{array}{l}\text { LH pulse amplitude§ } \\
7-8 \ddagger\end{array}$ & \multicolumn{6}{|c|}{$7-8 \ddagger$} \\
\hline Mean plasma LH§ & $3.5 \pm 0.3$ & $2.8 \pm 0.2$ & $4.9 \pm 0.4$ & $6.7 \pm 0.5$ & $3.5 \pm 0.1$ & $3.0 \pm 0.1$ \\
\hline No. LH pulses\| & 7 & 2 & 8 & 6 & 7 & 4 \\
\hline LH pulse amplitude§ & $2.3 \pm 0.9$ & $3.2 \pm 0.7$ & $3.9 \pm 1.4$ & $5.3 \pm 2.7$ & $1.5 \pm 0.1$ & $2.2 \pm 0.6$ \\
\hline
\end{tabular}

* 4-h study periods, $1200-1600 \mathrm{~h}$ and $2400-0400 \mathrm{~h}$. $\dagger$ 6-h study periods, $1200-1800 \mathrm{~h}$ and $2400-0600 \mathrm{~h}$. $\ddagger 9-\mathrm{h}$ study periods, $1200-2100 \mathrm{~h}$ and $2400-0900 \mathrm{~h}$. $\S \bar{x} \pm \mathrm{SE}(\mathrm{mIU} / \mathrm{ml})$.

|| Total number of detectable LH pulses.

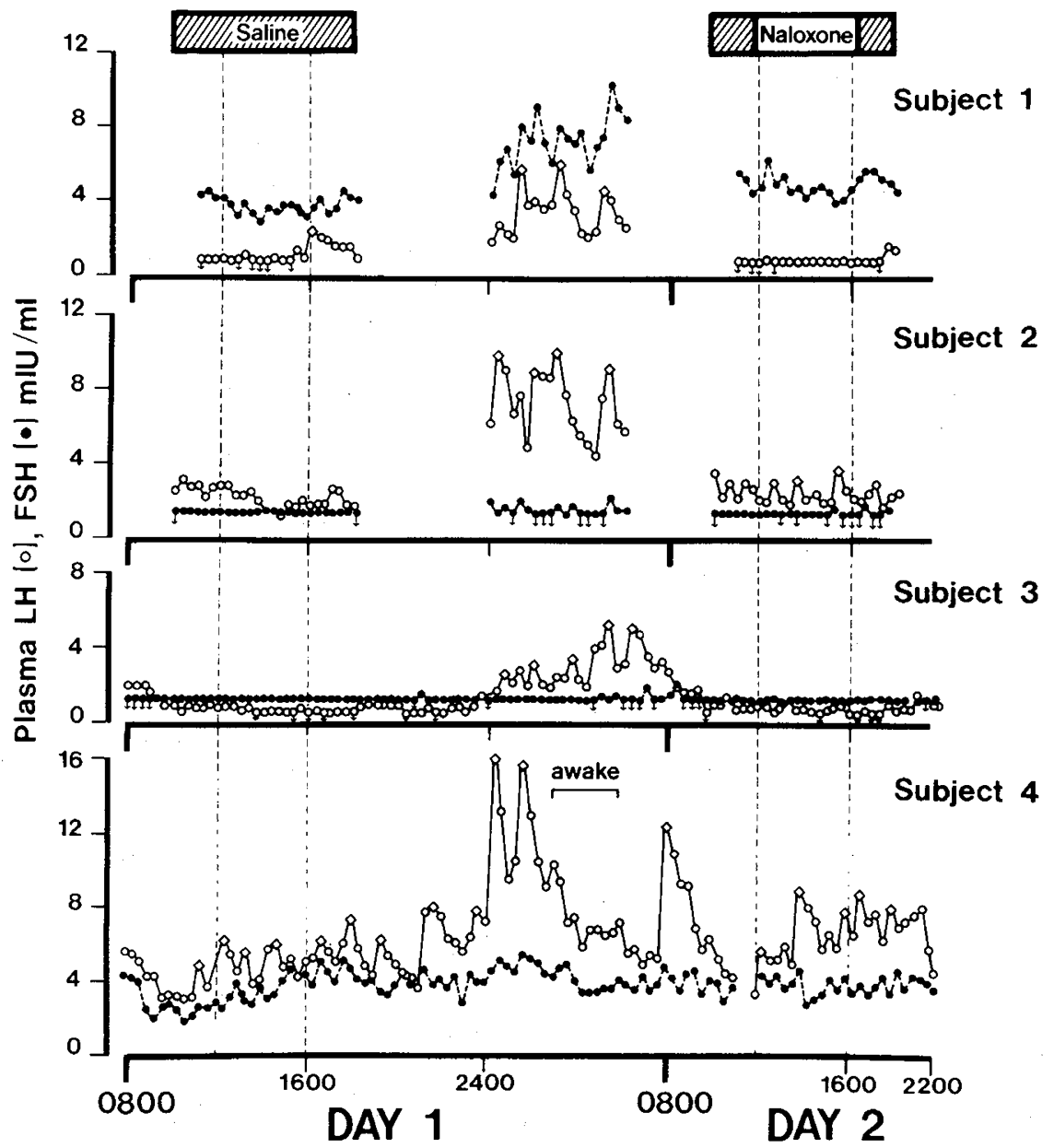

Fig. 1. Effect of opiate antagonism on daytime gonadotropin secretion in two late prepubertal (subjects 1 and 2 ) and two pubertal children (subjects 3 and 4). Saline was infused $\left(20 \mathrm{ml} / \mathrm{h}\right.$ ) on $\mathrm{d} 1$ and 2 (shaded bars) and naloxone $\left[1 \mathrm{mg} /\left(\mathrm{m}^{2} \cdot \mathrm{h}\right)\right]$ on $\mathrm{d} 2$ (open bar). Diamond symbols denote significant luteinizing hormone (LH) pulses. 


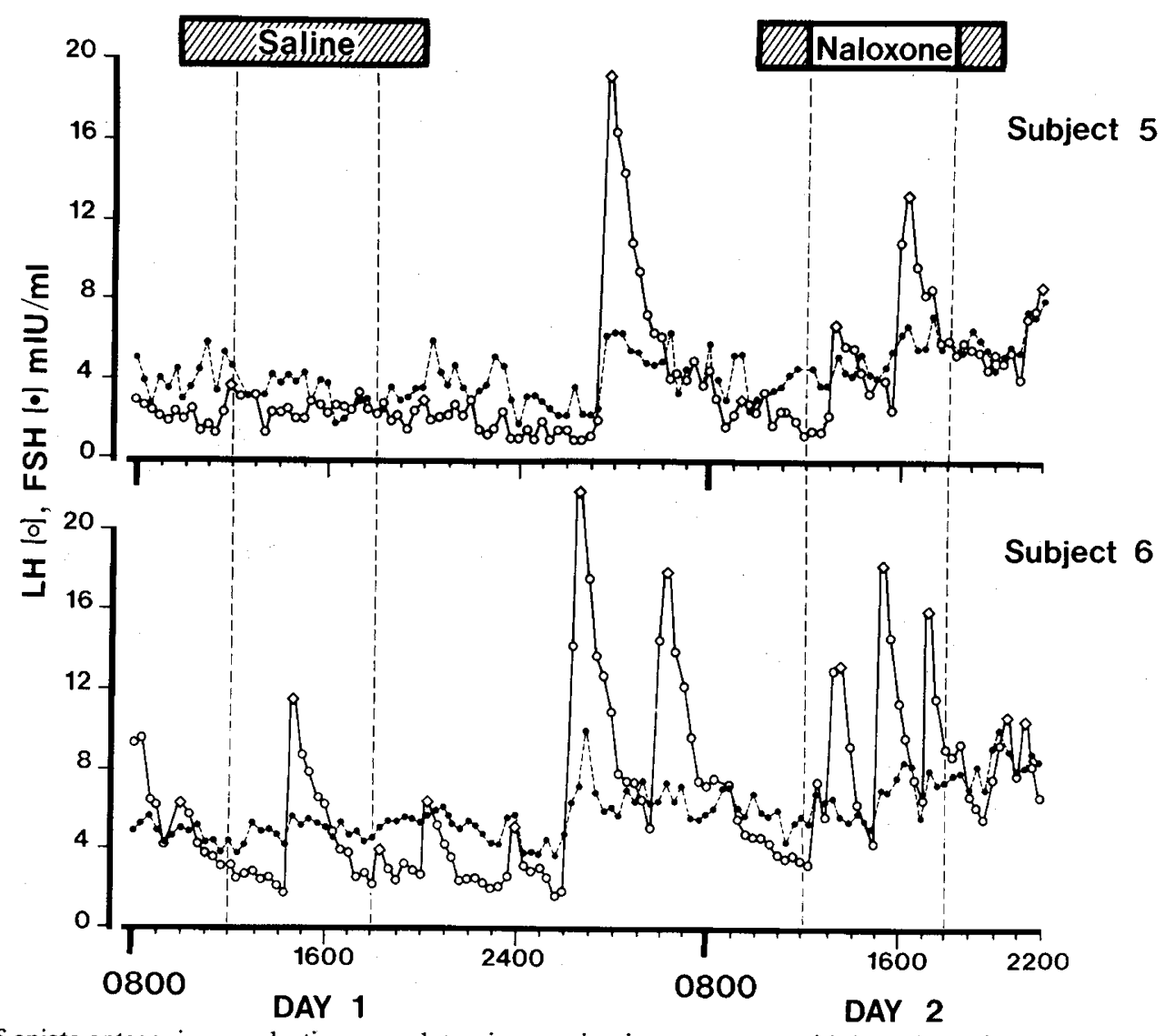

Fig. 2. Effect of opiate antagonism on daytime gonadotropin secretion in two women with hypothalamic amenorrhea at normal body weight. Saline was infused $(20 \mathrm{ml} / \mathrm{h})$ on $\mathrm{d} 1$ and 2 (shaded bars) and naloxone $\left[1 \mathrm{mg} /\left(\mathrm{m}^{2} \cdot \mathrm{h}\right)\right]$ on $\mathrm{d} 2$ (open bar). Significant luteinizing hormone (LH) pulses are designated by diamond symbols.

by his adult-type LH response to synthetic GnRH and his midpubertal plasma $\mathrm{T}$ concentrations (Table 1 ). In subject 2 , two significant $\mathrm{LH}$ pulses occurred during naloxone infusion whereas no pulses were detectable during the control day $(1200-1600 \mathrm{~h})$; however, mean gonadotropin concentrations during these two study periods did not differ significantly.

Naloxone produced a striking increase in plasma LH concentrations in the amenorrheic women (Figs. 2 and 3). In subjects 5 and 6, mean LH during naloxone equaled or exceeded that present during the preceding night (Table 2). LH increased steadily during naloxone infusion in subjects 7 and 8 . In both cases, the rise in LH was followed by an augmentation in plasma $E_{2}$, and mean plasma $L H$ was increased at night only during opiate receptor blockade (Fig. 3). LH decreased on day 2 as subject 8 awoke, approximately $2 \mathrm{~h}$ before the naloxone infusion was discontinued. LH pulse frequency increased in all four women during naloxone; $\mathrm{LH}$ pulse amplitude was augmented as well, particularly in subject 7 (Table 2, Figs. 2 and 3). Antagonism of endogenous opioid peptides resulted in a moderate increase in daytime FSH secretion in subjects 5 and 6 but had little effect on FSH in subjects 7 and 8.

Plasma PRL increased during sleep in the children and in the amenorrheic women at normal body weight (PRL, $\bar{x} \pm \mathrm{SE}$, day/ night: subjects $2-4,8.4 \pm 0.5 / 22.3 \pm 2.2$ and subjects 5 and 6 , $7.0 \pm 0.5 / 14.8 \pm 1.3 \mathrm{ng} / \mathrm{ml})$. In contrast, PRL did not rise at night in the two women at low body weight, though observations confirmed they were asleep (PRL day/night: subjects 7 and 8 , $8.6 \pm 1.1 / 9.5 \pm 0.8 \mathrm{ng} / \mathrm{ml}$ ). In all cases, opiate blockade by naloxone did not alter plasma PRL concentrations. Plasma cortisol was normal during control periods and did not change during naloxone infusion.

\section{DISCUSSION}

We reasoned that low pituitary sensitivity to GnRH present during mid-childhood (BA, 3-7 yr) might obscure any effect of naloxone on endogenous GnRH secretion; thus, we studied late prepubertal and pubertal children who showed evidence of increasing pituitary responsiveness such as pubertal-type gonadotropin responses to exogenous GnRH and a clear augmentation of LH secretion during sleep. Some women with secondary amenorrhea of unknown etiology, so-called hypothalamic amenorrhea, have gonadotropin secretory patterns that resemble those of prepubertal and early pubertal girls: basal $\mathrm{LH}$ concentrations are often low and the FSH/LH ratio is increased (12 and 30). Both of these abnormalities were present in the four amenorrheic women studied. In addition, two of the women had increased nocturnal LH secretion during the control day. The mechanisms responsible for immature patterns of gonadotropin secretion in women with hypothalamic amenorrhea are unknown. We compared the effects of opiate receptor blockade on gonadotropin secretion in these women with those in children.

Naloxone had no discernible effect during the day on mean gonadotropin concentrations in the late prepubertal and early pubertal children (subjects 1-3). This agrees with results of a similar study in early to mid-pubertal boys reported recently (28). Animal studies have shown a sex-dependent difference in the effect of naloxone on LH secretion: opiate antagonism increased LH in prepubertal female rats but had little effect in prepubertal male rats $(2,13)$. In contrast, the present study showed no change in gonadotropin secretion during naloxone in the prepubertal girl as well as in the late pre- and early pubertal boys.

The slight but discernible increase in LH during opiate receptor blockade in subject 4 , a mid-pubertal boy, is of particular interest. Naloxone clearly augments LH secretion in adult males (20). Results of the current study suggest that this effect of opiate antagonism on gonadotropin secretion first becomes detectable during puberty in males, and a similar age-related change was described by Veldhuis et al. (28). Studies in male rats support a role of endogenous opiates in T-dependent feedback control of 


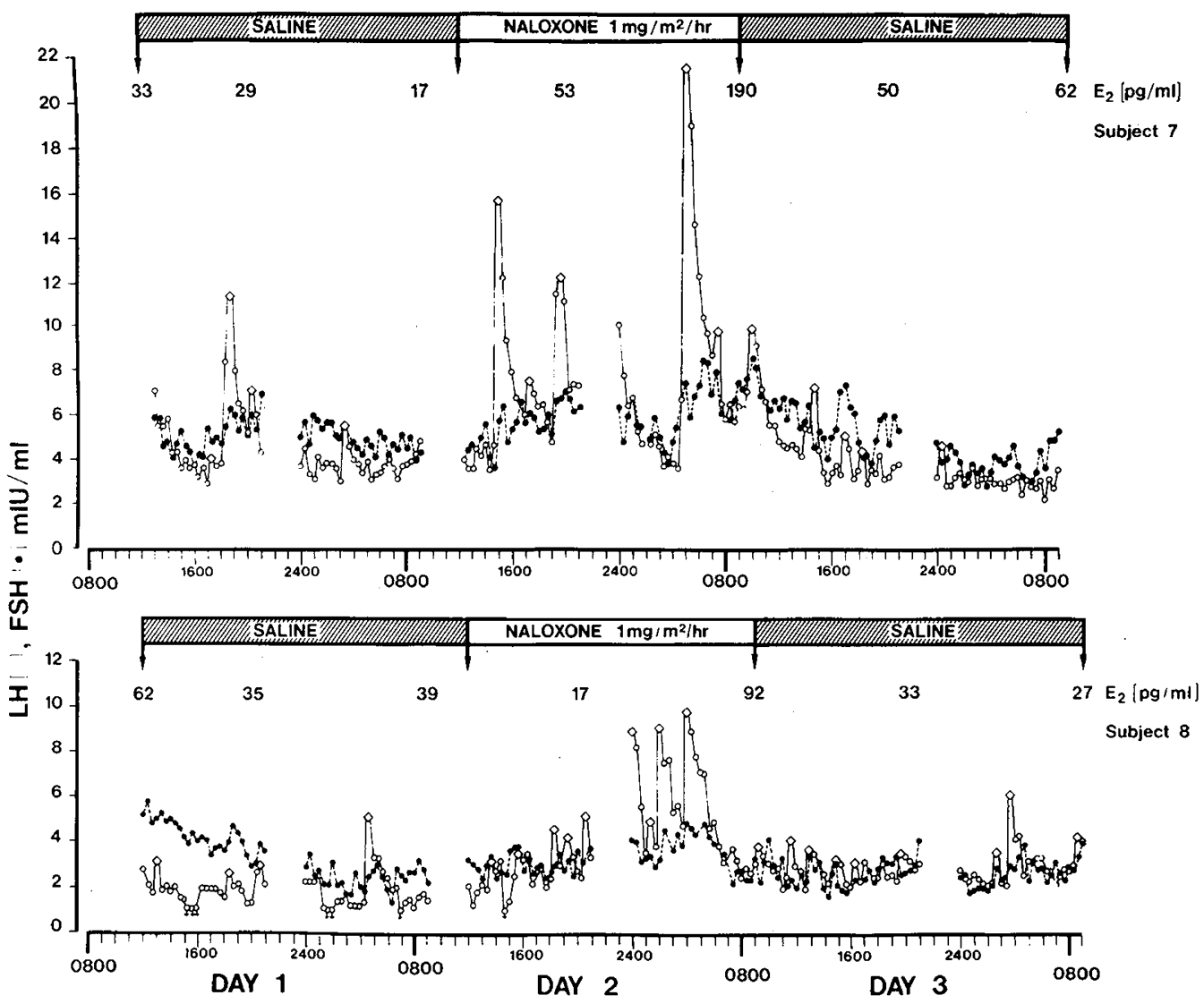

Fig. 3. Effect of opiate antagonism on 21-h gonadotropin secretory patterns in two women with hypothalamic amenorrhea at low body weight. Saline was infused $\left(20 \mathrm{ml} / \mathrm{h}\right.$ ) over $24 \mathrm{~h}$ on $\mathrm{d} 1$ and 3 (shaded bars). Naloxone was infused $\left(1 \mathrm{mg} /\left(\mathrm{m}^{2} \cdot \mathrm{h}\right)\right]$ on d 2 (open bar). Plasma $\mathrm{E}_{2}$ concentrations $(\mathrm{pg} / \mathrm{ml})$ determined at $12-\mathrm{h}$ intervals in both subjects are shown. Diamond symbols represent significant luteinizing hormone (LH) pulses. Note reversal of the follicle-stimulating hormone (FSH)/LH ratio in both women during naloxone.

LH (6). This suggests that rising serum $\mathrm{T}$ may be an important factor in augmenting the sensitivity of $\mathrm{LH}$ secretion to opiate receptor blockade during male puberty.

LH secretion increased strikingly during naloxone infusion in the amenorrheic women. This effect has been reported in patients with hypothalamic amenorrhea $(3,21)$. These findings indicate a role of endogenous opioid peptides in suppression of $\mathrm{LH}$ secretion in some women with secondary amenorrhea of unknown etiology. In the present study, the rate of episodic $\mathrm{LH}$ secretion was slow during control days in the women, ranging from $1-3.3$ pulses per $12 \mathrm{~h}$. LH pulse amplitude was low during control studies in subjects 5, 7, and 8 which may have led to an underestimation of the frequency of $\mathrm{LH}$ pulses. In the four adult subjects, opiate receptor blockade increased LH pulse frequency and resulted in slight augmentation of LH pulse amplitude. The effect of naloxone on pulse frequency was evident primarily during the night in the women at low body weight, subjects 7 and 8 . In two women (subjects 6 and 8), frequency rose to an average of one pulse per $2 \mathrm{~h}$, a rate normally found during the follicular phase of the menstrual cycle when serum $\mathrm{LH}$ is measured every $15-20 \mathrm{~min}(24,31)$. This effect of naloxone on $\mathrm{LH}$ pulses strongly suggests that endogenous opiates act at the hypothalamic level by changing GnRH pulse frequency.

A day/night difference in LH secretion was present on d 1 (control) in two women (subjects 5 and 6), which is similar to the findings in children. In contrast to the results in children, however, antagonism of endogenous opiate activity increased daytime LH secretion in these women. This suggests that the mechanisms responsible for the reduced LH secretion in women with hypothalamic amenorrhea differ from those in late prepubertal and early pubertal children. Furthermore, the immature patterns of gonadotropin secretion found in some amenorrheic women cannot be attributed simply to a regression of the hypothalamic-pituitary-gonadal axis to a pre- or early pubertal state.
The marked increase in $\mathrm{LH}$ secretion during opiate receptor blockade in the two women at low body weight (subjects 7 and 8) contrasts with results of studies by Grossman et al. (10). These investigators found that naloxone had little effect on gonadotropin secretion in women with weight loss-related amenorrhea. This discrepancy may be due to the fact that our patients received naloxone for a longer period of time than did patients in the previously reported study (10). Subjects 7 and 8 had a nocturnal increase in LH secretion only during opiate antagonism (d 2). On control d 1 and 3, LH was uniformly low during the day and night. Boyar et al. (4) found a day/night difference in gonadotropin concentrations in four of nine women with anorexia nervosa at low body weight; plasma LH was suppressed throughout the 24-h study period in the remaining five women. The study of subject 8 is particularly informative regarding the role of endogenous opiates in determining this day/night difference. Plasma LH fell on d 2 as subject 8 awoke, approximately $2 \mathrm{~h}$ before naloxone was discontinued; thus, augmented nocturnal $\mathrm{LH}$ secretion was associated with sleep and was not determined solely by opiate receptor blockade. Antagonism of endogenous opioid peptides in these women apparently unmasked a day/night difference in gonadotropin secretion.

\section{REFERENCES AND NOTES}

1. Bacon, G. E., Spencer, M. L., and Kelch, R. P.: Effect of cortisol treatment on hormonal relationships in congenital adrenal hyperplasia. Clin. Endocrinol., 6: 113 (1977).

2. Blank, M. S., Panerai, A. E., and Friesen, H. G.: Opioid peptides modulate luteinizing hormone secretion during sexual maturation. Science, 203: 1129 (1979).

3. Blankstein, J., Reyes, F. L., Winter, J. S. D., and Faiman, C.: Endorphins and the regulation of the human menstrual cycle. Clin. Endocrinol., 14: 287 (1981).

4. Boyar, R. M., Katz, J., Finkelstein, J. W., Kapen, S., Weiner, H., Weitzman, E. D., and Hellman, L.: Anorexia nervosa: immaturity of the 24-hour luteinizing hormone secretory pattern. N. Engl. J. Med., 291: 861 (1974). 
5. Buster, J. E. and Abraham, G. E.: Radioimmunoassay of plasma dehydroepiandrosterone sulfate. Anal. Lett., 5: 543 (1972).

6. Cicero, T. J., Schainker, B. A., and Meyer, E. R.: Endogenous opioids participate in the regulation of the hypothalamic-pituitary-luteinizing hormone axis and testosterone's negative feedback control of luteinizing hormone. Endocrinology, 104: 1286 (1979).

7. Conte, F. A., Grumbach, M. M., Kaplan, S.L., and Reiter, E. O.: Correlation of luteinizing hormone-releasing factor-induced luteinizing hormone and follicle-stimulating hormone release from infancy to 19 years with the changing pattern of gonadotropin secretion in agonadal patients: relation to the restraint of puberty. J. Clin. Endocrinol. Metab., 50:163 (1980).

8. Drouva, S. V., Epelbaum, J., Tapia-Arancibia, L., Laplante, E., and Kordon, C.: Met-enkephalin inhibition of $\mathrm{K}^{+}$-induced LHRH and SRIF release from rat mediobasal hypothalamic slices. Eur. J. Pharmacol., 61: 411 (1980).

9. England, B. G., Niswender, G. D., and Midgley, A. R., Jr.: Radioimmunoassay of estradiol $17-\beta$ without chromatography. J. Clin. Endocrinol. Metab., 38 : 42 (1974).

10. Grossman, A., Moult, P. J. A., McIntyre, H., Evans, J., Silverstone, T., Rees, L. H., and Besser, G. M.: Opiate mediation of amenorrhoea in hyperprolactinaemia and in weight-loss related amenorrhoea. Clin. Endocrinol., 17: 379 (1982).

11. Gruelich, W. W. and Pyle, S. L.: Atlas of Skeletal Development of the Hand and Wrist. 2nd ed. (Stanford University Press, Stanford, 1955).

12. Grumbach, M. M., Roth, J. C., Kaplan, S. L., and Kelch, R. P.: Hypothalamicpituitary regulation of puberty in man: evidence and concepts derived from clinical research. In: M. M. Grumbach, G. D. Grave, and F. E. Mayer: Control of the Onset of Puberty. p. 115 (John Wiley and Sons, Inc., New York, 1972)

13. Ieiri, T., Chen, H. T., and Meites, J.: Effects of morphine and naloxone on serum levels of luteinizing hormone and prolactin in prepubertal male and female rats. Neuroendocrinology, 29:288 (1979).

14. Ismail, A. A., Niswender, G. D., and Midgley, A. R., Jr.: Radioimmunoassay of testosterone without chromatography. J. Clin. Endocrinol. Metab., 34. 177 (1972).

15. Jakacki, R. I., Kelch, R. P., Sauder, S. E., Lloyd, J. S., Hopwood, N. J., and Marshall, J. C.: Pulsatile secretion of luteinizing hormone in children. J. Clin. Endocrinol. Metab., 55: 453 (1982).

16. Kelch, R. P., Grumbach, M. M., and Kaplan, S. L.: Studies on the mechanism of puberty in man. In: B. B. Saxena, C. G. Belin, and H. M. Gandy: Gonadotropins. p. 254 (John Wiley and Sons, Inc., New York, 1972).

17. Keye, W. R., Jr. and Jaffe, R. B.: Strength-duration characteristics of estrogen effects on gonadotropin response to gonadotropin-releasing hormone in women. I. Effects of varying duration of estradiol administration. J. Clin. Endocrinol. Metab., 41: 1003 (1975).

18. Midgley, A. R., Jr.: Radioimmunoassay: a method for human chorionic gonadotropin and human luteinizing hormone. Endocrinology, 79: 10 (1966).

19. Midgley, A. R., Jr.: Radioimmunoassay for human follicle-stimulating hor- mone. J. Clin. Endocrinol. Metab., 27: 295 (1967).

20. Morley, J. E., Baranetsky, N. G., Wingert, T. D., Carlson, H. E., Hershman, J. M., Melmed, S., Levin, S. R., Jamison, K. R., Weitzman, R., Chang, R. $\mathrm{J}$., and Varner, A. A.: Endocrine effects of naloxone-induced opiate receptor blockade. J. Clin. Endocrinol. Metab., 50: 251 (1980).

21. Quigley, M. E., Sheehan, K. L., Casper, R. F., and Yen, S. S. C.: Evidence for increased dopaminergic and opioid activity in patients with hypothalamic hypogonadotropic amenorrhea. J. Clin. Endocrinol. Metab., 50: 949 (1980).

22. Quigley, M. E. and Yen, S. S. C.: The role of endogenous opiates on LH secretion during the menstrual cycle. J. Clin. Endocrinol. Metab., 51: 179 (1980).

23. Reiter, E. O. and Grumbach, M. M.: Neuroendocrine control mechanisms and the onset of puberty. Annu. Rev. Physiol., 44: 595 (1982).

24. Santen, R. J. and Bardin, C. W.: Episodic luteinizing hormone secretion in man. J. Clin. Invest., 52: 2617 (1973).

25. Sauder, S. E., Corley, K. P., Hopwood, N. J., and Kelch, R. P.: Subnormal gonadotropin responses to gonadotropin-releasing hormone $(\mathrm{GnRH})$ persist into puberty in children isolated growth hormone deficiency (IGHD). J. Clin. Endocrinol. Metab., 53: 1186 (1981).

26. Sinha, Y. N., Selby, F. W., Lewis, U. J., and Vanderlaan, W. P.: A homologous radioimmunoassay for human prolactin. J. Clin. Endocrinol. Metab., 36: 509 (1973).

27. Stubbs, W. A., Delitala, G., Jones, A., Jeffcoate, W. J., Edwards, C. R. W., Ratter, S. J., Besser, G. M., Bloom, S. R., and Alberti, K. G. M. M.: Hormonal and metabolic responses to an enkephalin analogue in normal man. Lancet, 2: 1225 (1978).

28. Veldhuis, J. D., Kulin, H. E., Warner, B. A., and Santner, S. J.: Responsiveness of gonadotropin secretion to infusion of an opiate-receptor antagonist in hypogonadotropic individuals. J. Clin. Endocrinol. Metab., 55: 649 (1982).

29. Wilkes, M. M. and Yen, S. S. C.: Augmentation by naloxone of efflux of LRF from superfused medial basal hypothalamus. Life Sci., 28: 2355 (1981).

30. Yen, S. S. C.: Chronic anovulation due to CNS-Hypothalamic-Pituitary Dysfunction. In: S. S. C. Yen and R. B. Jaffe: Reproductive Endocrinology. p. 341 (W. B. Saunders Company, Philadelphia, 1978).

31. Yen, S. S. C. Tsai, C. C. Naftolin, F. Vandenberg, G., and Ajabor, L.: Pulsatile patterns of gonadotropin release in subjects with and without ovarian function. J. Clin. Endocrinol. Metab., 34:671 (1972).

32. The authors gratefully acknowledge the expert technical assistance of Ms. M Markovs, Ms. R. Jakacki, Ms. K. Kersey, and Ms. A. Petzold, the excellent secretarial support of Ms. B. Vibbart, and the assistance of the nursing staff of the CRC. Synthetic LRF (GnRH) was supplied by Parke-Davis/WarnerLambert Co., (Detroit, MI).

33. Requests for reprints should be addressed to: Dr. S. E. Sauder, F2125 C. S. Mott Children's Hospital, Ann Arbor, MI 48109.

34. This research was supported by grants HD 16000 and Clinical Research Center Grant 5M01-RR42.

35. Received for publication February 7, 1983.

36. Accepted for publication June $27,1983$. 